\title{
Mineralization Information Extraction and Gold Deposit Assessment in Yanfolila, Southern Mali, West Africa
}

\author{
Fodé Tounkara ${ }^{1,2}$, Jianguo Chen ${ }^{1,2}$, Ahmed Amara Konaté ${ }^{3}$, Chengbin Wang1,2 \\ ${ }^{1}$ State Key Laboratory of Geological Processes and Mineral Resources, China University of Geosciences (Wuhan), Wuhan, China \\ ${ }^{2}$ Faculty of Earth Resource, China University of Geosciences (Wuhan), Wuhan, China \\ ${ }^{3}$ Institute of Geophysics and Geomatics, China University of Geosciences (Wuhan), Wuhan, China \\ Email: ^fode1986@yahoo.fr
}

How to cite this paper: Tounkara, F., Chen, J.G., Konaté, A.A. and Wang, C.B. (2017) Mineralization Information Extraction and Gold Deposit Assessment in Yanfolila, Southern Mali, West Africa. Open Journal of Geology, 7, 1327-1336.

https://doi.org/10.4236/ojg.2017.79088

Received: July 10, 2017

Accepted: September 8, 2017

Published: September 11, 2017

Copyright (c) 2017 by authors and Scientific Research Publishing Inc. This work is licensed under the Creative Commons Attribution International License (CC BY 4.0).

http://creativecommons.org/licenses/by/4.0/

\begin{abstract}
The Yanfolila study area is located in the province of gold, south of Mali. Gold is the main mineral resource of Mali. No enough reserve deposit, so there is a need to assess gold deposit. To evaluate the gold deposit, the appropriate method is as follows. The first task is the geological interpretation of study area, which has been one of the major works. The second task is to interpret geochemical soil data. The processing of geochemical data requires the most commonly used methods of spatial analysis. We tried to delineate new target areas for finding undiscovered gold deposits. Finally, the integrated interpretation maps coming from the combination of the different map, referring to the fault information which is verified during fieldwork. Some faults are relatively small scale, widely distributed, and configured for various levels of influence on gold mineralization. In this case, the Banifing fault system is the factor controlling the mineralization process in the region. The findings show two targets delineated in the study area. Solona (target 1), the contours of this zone coincides with igneous rock, which has been encountered as a highly altered material. Target 2 is located in the center of Yanfolila area, and it is less important than target 1 .
\end{abstract}

\section{Keywords}

Banifing Fault, Gold Deposit Assessment, Integrated Interpretation, Yanfolila

\section{Introduction}

Gold is the main mineral resource of Mali. In 2010, gold accounted for 95\% of 
the total estimated value of minerals produced in the country. In Mali, a less developed country, gold export has substantially increased in the 1990s [1]. Mali suffers from artisanal and small-scale mining formalization problem as other mineral rich countries in the region [2].

Unfortunately, recent decades have seen a considerable reduction of national capacities to ensure the geochemical survey and remote sensing survey to produce qualitative information tailored to country needs. Sustainable management of the gold resources is a major issue for the Mali. For this, each country needs data and information enabling it to monitor and predict the evolution of the gold resource.

The methods will be employed quickly and cost-effectively. According to the available literature [3] [4] [5], there is limited research on the gold resource in Yanfolila. The integration of those techniques will be of great importance as it will provide accurate mineralization information to understand gold mineralizing systems.

\section{Location of Study Area}

The Yanfolila study area is located in the province of gold, Kalana-Kodieran, south of Mali in West Africa (Figure 1). It is about $230 \mathrm{~km}$ south of the capital Bamako, situated in the following coordinates:

Latitude $11^{\circ} 10^{\prime} 00^{\prime \prime} \mathrm{N}$ and longitude $8^{\circ} 12^{\prime} 00^{\prime \prime} \mathrm{W}$,

Latitude $11^{\circ} 10^{\prime} 00^{\prime \prime} \mathrm{N}$, longitude $9^{\circ} 12^{\prime} 00^{\prime \prime} \mathrm{W}$,

Latitude $12^{\circ} 10^{\prime} 00^{\prime \prime} \mathrm{N}$ and longitude $8^{\circ} 12^{\prime} 00^{\prime \prime} \mathrm{W}$,

Latitude $12^{\circ} 10^{\prime} 00^{\prime \prime} \mathrm{N}$, longitude $9^{\circ} 12^{\prime} 00^{\prime \prime} \mathrm{W}$.

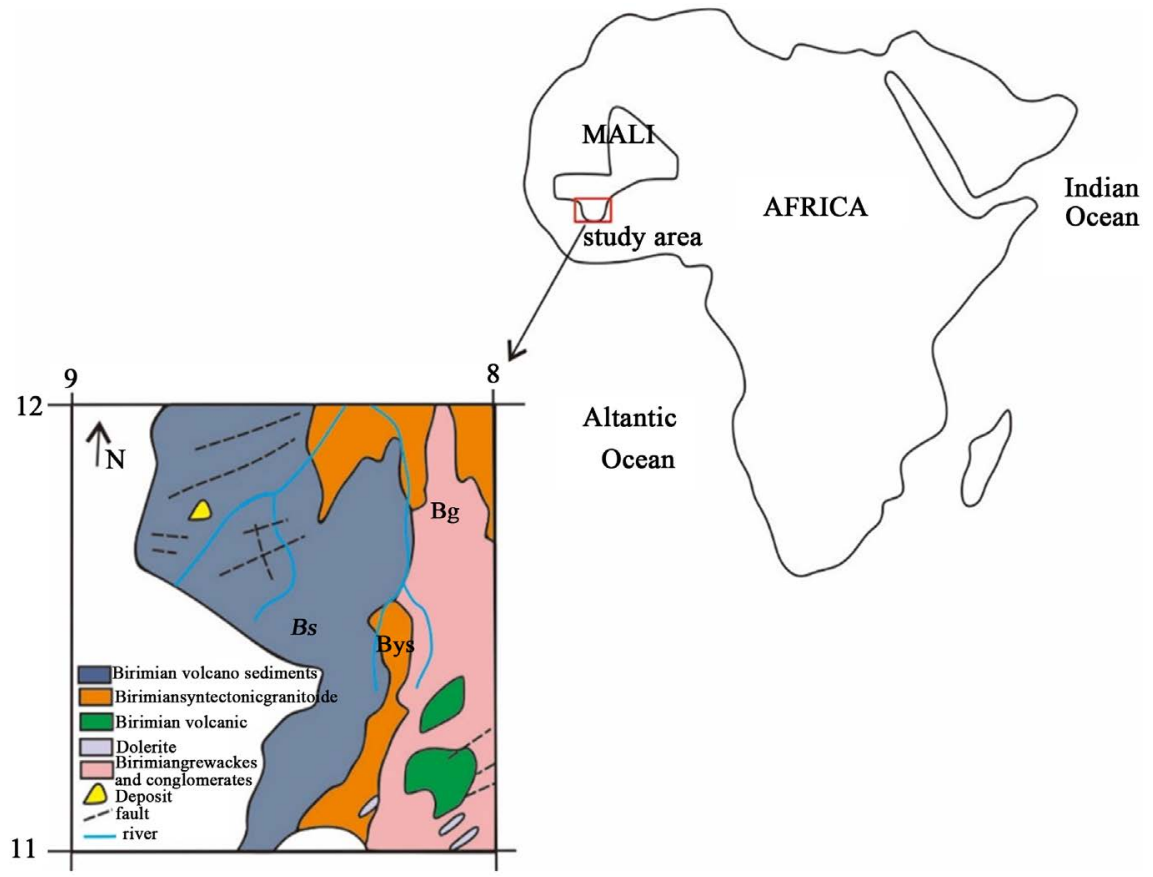

Figure 1. Location and regional geology map of study area. 


\section{Geological Setting}

\subsection{Regional Geology}

The geology of the southern part of Mali is characterized by Precambrian basement rocks of the West-African craton which are comprised of the Man (south) and Reguibat (north) shields, and significantly smaller inliers of Kenieba and Kayes. These exposed basements blocks are bounded and separated by Pan-African fold belts and Late Proterozoic to Phanerozoic sedimentary basins, including the expansive Taoudeni basin. The Man shield is subdivided into three main lithostratigraphic units: The Liberian shield of Archean age, and the Birimian and Tarkwaian, which are considered to be Early Proterozoic [6] [7].

Moreover, the geology of the southern part of Mali is made up of a volcano-sedimentary sequence of Birimian rocks, tightly folded, but weakly metamorphosed during the Eburnean orogeny $(2.1 \mathrm{Ga})$ and intruded by syn-to late-tectonic granites (Figure 1). The Birimian rocks comprise a series of fine-grained sedimentary and volcanic rocks. The sedimentary sequence consists of meta-arenite, meta-argillite, meta-greywacke and meta-carbonates. The volcanic formations are comprised of andesite tuffs, basalts, and dacites rocks with mafic components predominating.

Southern Mali is bound on to the north and east by the Taoudeni Basin comprising Upper Mid- to Late-Proterozoic sandstones and interbedded pebble conglomerates of the Taoudeni basin (often termed the Infra-Cambrian), that unconformably overlie the Birimian rocks. Both the sedimentary and volcanic sequences are cross-cut by dolerite, diorite, and keratophyre dikes. The geological setting of the Yanfolila concession area has been previously mapped and described by [8] [9] [10] [11].

\subsection{Structural Setting}

The Bale Gold province, which hosts the Kalana and Kodieran gold deposits, is located in a north-south trending anticline around $150 \mathrm{~km}$ long and $40 \mathrm{~km}$ wide which is intersected by three fault systems [12]. This structure covers an area of $6000 \mathrm{~km}^{2}$, including the Yanfolila zone.

The north-northeast trending Banifing fault is the largest fault in southern Mali and is believed to have a left-lateral relative displacement with many sub-parallel shears. This fault has been traced for a strike length of more than $500 \mathrm{~km}$. The faulting is accompanied by gold-bearing quartz veins and veinlets with, four principal attitudes that can range from several $\mathrm{mm}$ to several meters in width. The first three vein systems carry the gold mineralization.

\section{Data and Research Methodology}

The first task is the geological interpretation of study area, which has been one of the major works. The second task is to interpret geochemical soil data. The processing of geochemical data requires the most commonly used methods of spatial analysis. We tried to delineate new target areas for finding undiscovered gold depo- 
sits.

Geochemical soil sampling was conducted to the study area, in which over 763 samples collected (Figure 2). The objective of the sampling is to take a representative part of a whole or muchore to determine with the greatest possible precision the average content of various elements of the whole. All samples were submitted to the ALS Chemex laboratories in Mali's capital Bamako for analysis of gold. All the samples concerned were then analyzed for gold by $50 \mathrm{~g}$ pyro analysis (FA) using AAS finishing (Au-AA24 method).

After GIS treatment of regional geochemical data, the analytical and statistical results indicate some foreground anomalies (Figure 3). Finally, the integrated interpretation maps coming from the combination of the different map, referring to the fault information verified during fieldwork.

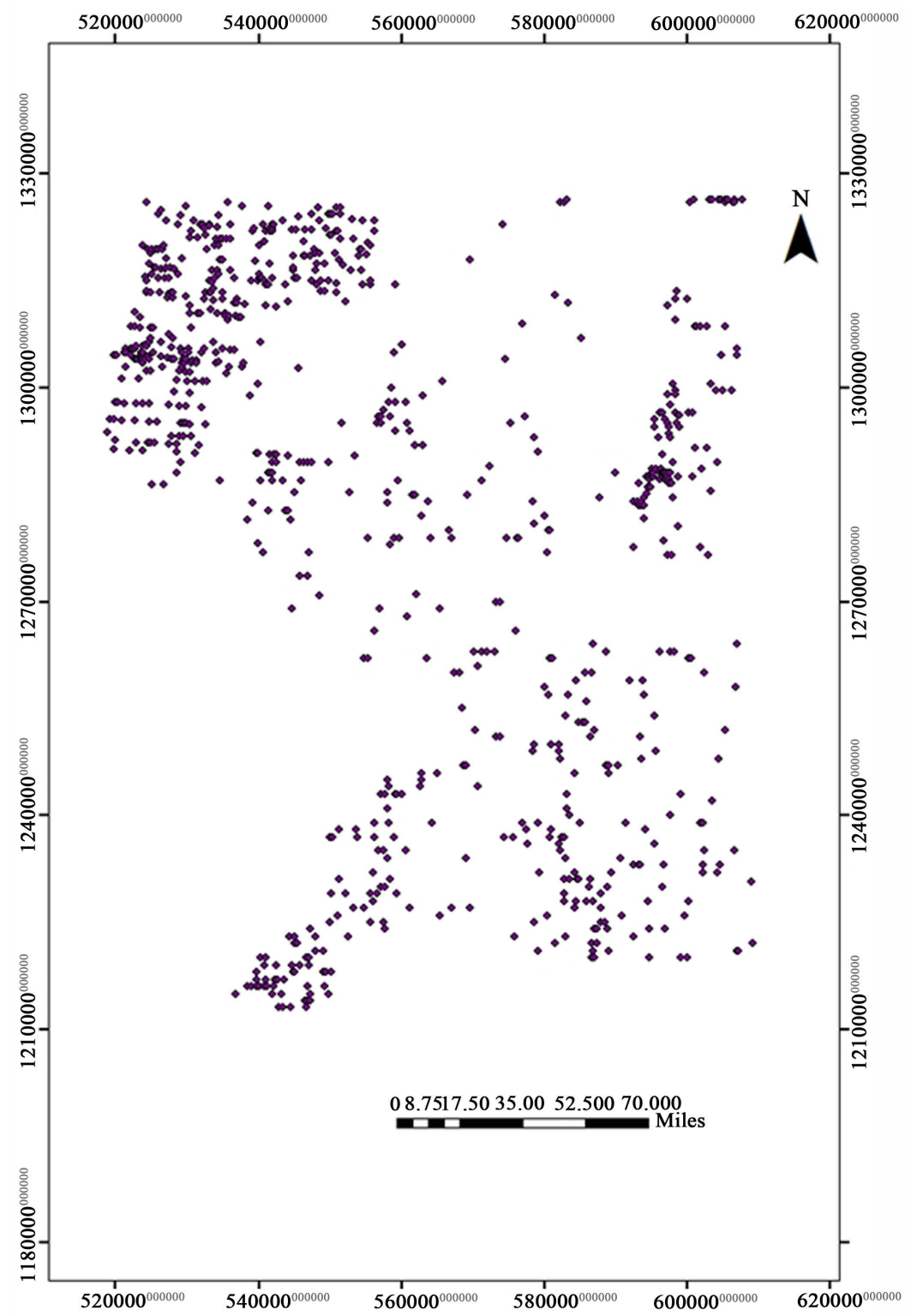

Figure 2. Geochemical soil sampling map of Yanfolila. 


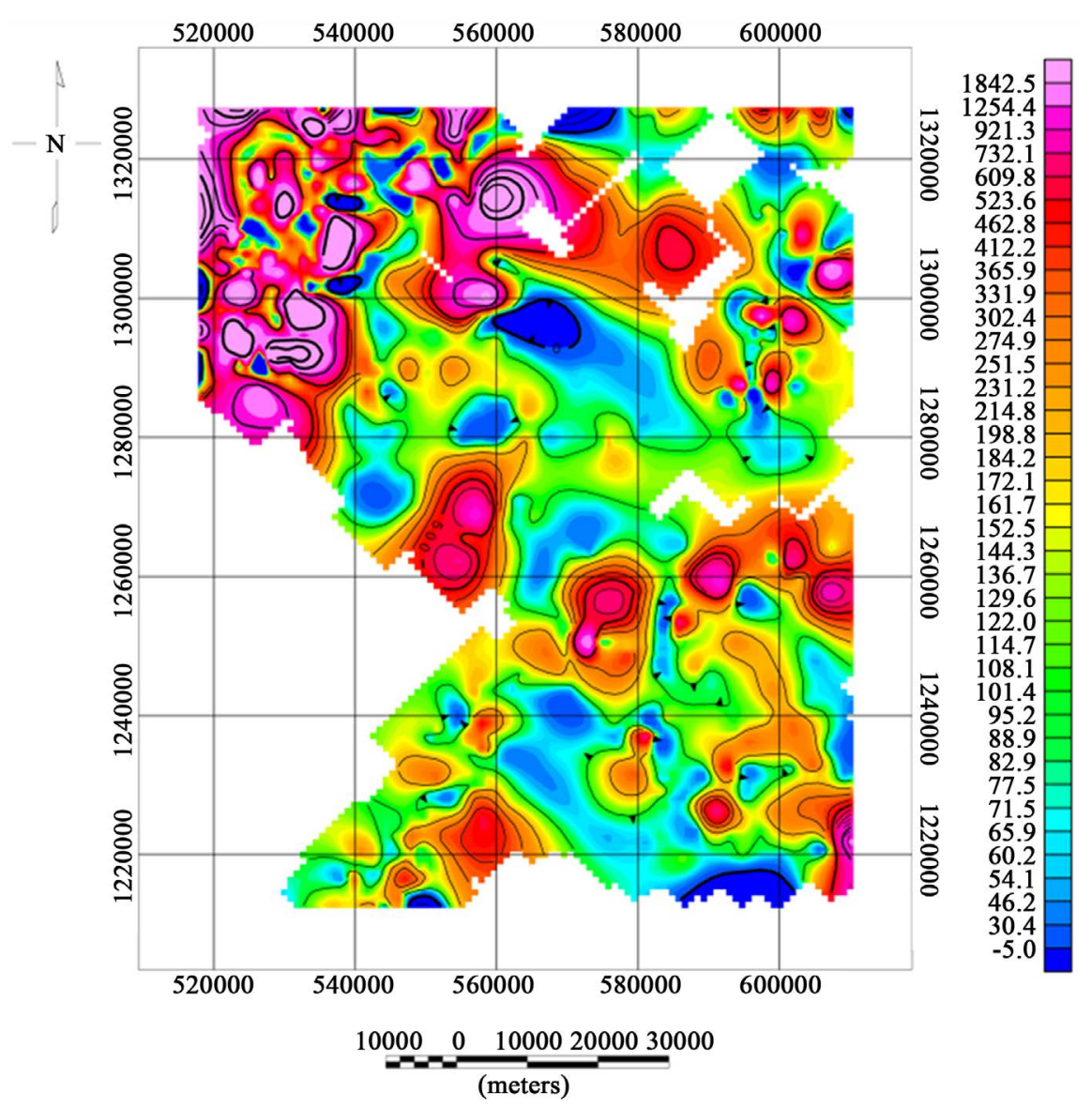

Figure 3. The regional geochemical gold anomalies map of Yanfolila.

\section{Results and Discussion}

\subsection{Integrated Interpretation}

Interpretation Map summarizes the relationship between the geological formation boundary and the mineralization index of gold and the source of location (Figure 4).

The use of existing geological data to test the work was done inside; here we illustrate some typical structures in the study area.

The effect of structures affects different levels of mineralization in the study area. Some faults are relatively small scale, widely distributed, and configured for various levels of influence on gold mineralization (Figure 4). The banifing fault (F1) system is the factor controlling the mineralization process in the region and plays on the impact of training of mineralization rocks.

Depending on the spatial distribution of the alteration anomaly and the degree of intensity of the alteration force, the information on the alteration of iron is closely related to the mineralization of rocks/process. As field relationships and micro-textural data indicate that the primary gold mineralization is shear hosted.

The high gold anomaly value is limited to the west and south, where gold values are low in breastplates and alluvial soils. The geochemical anomalies associated 


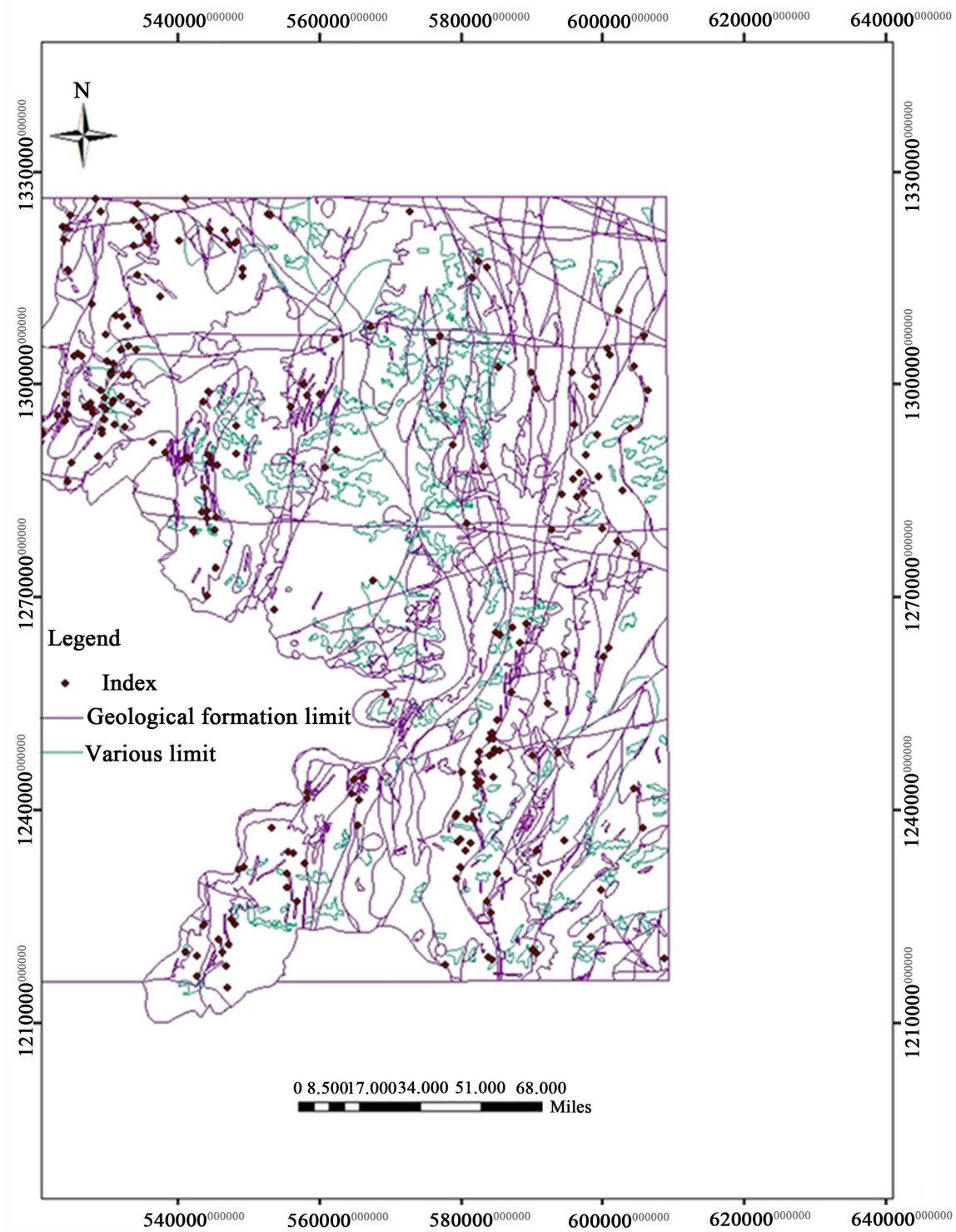

Figure 4. Interpretation map of relationship between geological formation limit and mineralization index of gold.

with the mineralization are controlled by the fault system. The degree of development of the lineaments and the overall interpretation of their spatial distribution reflects the structural setting of the study area. The results showed that the advantages of the orientation of regional lineaments to NE. While field relationships and micro-textural data indicate that the primary gold mineralization is shear hosted [13]. In Hoggar, gold mineralization depends on a double control, first order giant sub-meridian shear zone control and the gold districts disposed in N40 -50 E corridors that may be interpreted as extensional [14].

In this work the Banifing fault (F1) is the biggest fault, and supposed to have a relative moving in left-side with lots of sub-parallel shears. Clearly noticed that this fault on remote sensing maps. In southern Mali, the other north trends structures are considered co-genetics Banifing fault system. The gold occurrences are 
spatially controlled by the system of NNW and NNE trending faults. Both trends structures could also be interpreted in terms of structural corridors Banifing. While Gold deposits in the Syama and Tabakoroni goldfields in southern Mali occur along a north-northeast trending mineralized litho-structural corridor that trends for approximately $40 \mathrm{~km}$ [15].

The granite massif lying north several kilometers in length (Figure 5). This granite massif contains orthogneisses diorite rocks and monzonitic. It is considered a syn-tectonic intrusion often associated with hornfels, amphibolite quality contact metasomatic and local migmatization.

Small groups of diorite, granodiorite and porphyry plagiogranite also infringe the volcano-sedimentary sequence. These types of rocks are located at the intersection of the northwest and north-east fault (Figure 5). In general, the intrusive rocks of the region have a spatial affinity, combining them with local structures is considered particularly important in the location of the all the main gold deposits in southern Mali. However, the Tellem gold prospect is hosted by intrusive rocks of diorite to porphyry dacitic composition that crosscut the pyroclastic and black shale formation [16]. In the Oudalan-Gorouol, Gold mineralization

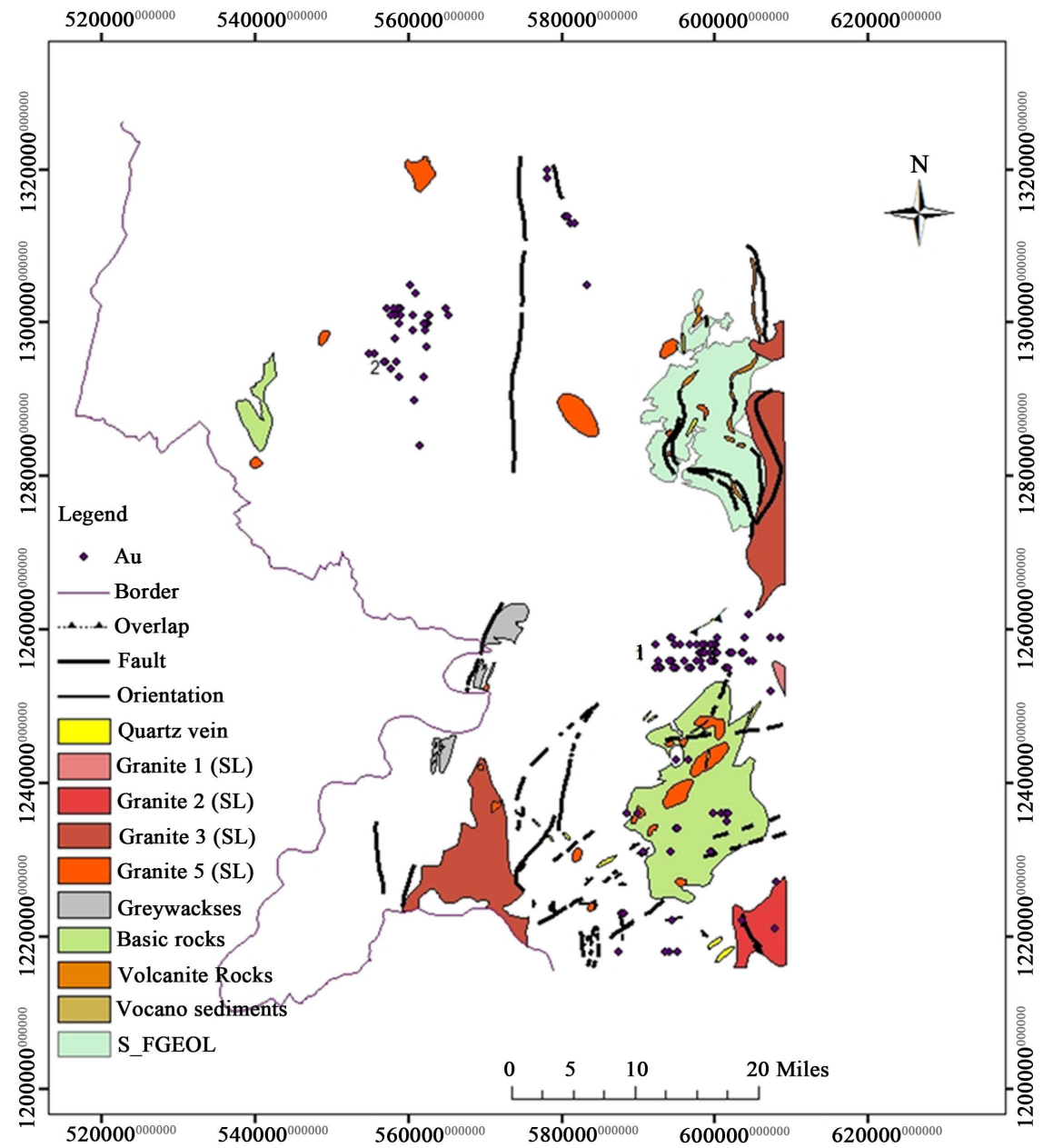

Figure 5. Interpretation map with target 1, 2 of gold prospect $(\mathrm{Au}>2 \mathrm{~g} / \mathrm{t})$. 
is sited along five northwest-trending metallogenic corridors, specifically, where northeast-trending faults and shears crosscut or coalesce with northwest-trending thrustfolds [17]. The creation of a deep laterite weathering profile and supergene enrichment of the residuum probably took place during the mid-Cretaceous-early Tertiary [18].

\subsection{Delineation and Assessment}

The integrated interpretation map from the combination of the different maps, referring to the geological information in association with the gold content greater than $2 \mathrm{~g} / \mathrm{t}$, allowed delimiting target by ArcGIS 10.2.1. The findings show two targets delineated in the study area. In the study area, two targets have been delineated.

In Solona (target 1), this zone is associated with geological structures. The contours of this zone coincide with igneous rock, which has been encountered as a highly altered material. Clay (kaolin) and ferric iron are the main alterations of the mineralized zone. On the interpretation map, target 2 is located in the center of Yanfolila area, and it is less important than target 1.

In The Yanfolila study area, Mineralization is associated with well-developed NNE and ENE structures. The presence of diorite intrusions approximately mineral showings, Quartz-sulphide vein, and veinlet develop with associated gold values.

The integrated interpretation indicates several gold anomalies coincide with broad areas. The general distribution number of lower-intensity gold anomalies within the study area. While in the Loulo-Gounkoto complex these findings demonstrate the widespread if heterogeneously distributed, nature of fluid mixing as an ore-forming process [19]. On the interpretation map (Figure 5), the delimitation of the target 1is located in the locality of SOLONA.

Clay (kaolin) and ferric iron (Fe.) are the main alterations of the mineralized zone. The presence of crates observed in oxidized meta-sedimentation indicates a probable sulfide $\left(\mathrm{SO}_{4}\right)$ mineralization. The results of the sample also confirmed that the Solona mineralization, which is believed to be controlled by NE structures intersected by secondary E-W structures.

The Solona area is mainly characterized by volcano sedimentary formations composed of slightly metamorphosed fine-grained sandstone, argillite, and siltstone.

\section{Conclusions}

This paper studies the mineral resources evaluation method. The following is the main conclusion on a gold prospect in Yanfolila southern Mali.

At present, a new understanding is that the presence of Banifing fault system explains the tectonic environment involved in the study area. The close combination, between geological data and geochemical data processing, given a comprehensive analysis of mineralization system. Finally, Solona gold prospect (tar- 
get 1) is considered as a discovered gold deposit in this area. In this paper, the integrated interpretation has been of great importance as it provides information to understand gold mineralizing systems in Yanfolila. Through the comprehensive qualitative and comparative analysis, it has been possible to recognize the geological rocks and structures.

\section{Acknowledgements}

This study research has been financially supported by the Minister of Mining of Maliunder (SYSMIN PROJECT 2002), that we would like to thank sincerely. Special thanks to my supervisor in state key laboratory of geological processes and mineral resources, China University of Geosciences, Wuhan. Thanks also all colleagues from National School of Engineers Abderhamane Baba TOURE of MALI for their advice.

\section{References}

[1] Mainguy, C. (2011) Natural Resources and Development: The Gold Sector in Mali. Resources Policy, 36, 123-131. https://doi.org/10.1016/j.resourpol.2010.10.001

[2] Teschner, B.A. (2014) Orpaillage Pays for Everything: How Artisanal Mining Supported Rural Institutions Following Mali's coup d'état. Futures, 62, 140-150. https://doi.org/10.1016/j.futures.2014.04.016

[3] Feybess, G. (2006) Notice explicative de la carte géologique de la republique du Mali à $1 / 200000$. UNESCO, Paris.

[4] Feybesse (2006) Synthese geologique du birimien malien edition Sysmin. Unpublished Report.

[5] Jean-Louis, F., Sidibé, Y.T., Konaté, C.M., Lacomme, A., Guerrot, C., Miehé, J., Lamberti, A., Zammit, C., MMIT5, BRGM, CPG and DNGM (2006) Carte géologique de la République du Mali à 1/200000, Feuille $\mathrm{n}^{\circ}$ NC-29-XXII, Yanfolila-Bamako (MALI). Unpublished Report.

[6] Guerrot, BRGM, CPG and DNGM (2006) Notice explicative de la Carte géologique de la République du Mali à 1/200000, Feuille ${ }^{\circ}$ ND-29-IV, Yanfolila XXII.-Bamako (MALI). Unpublished Report.

[7] Guerrot, Miehé, J.-M., Lamberti, A., Zammit, C., BRGM, CPG and DNGM (2006) Synthèse géologique du Birimien malien.-Bamako (MALI). Unpublished Report.

[8] Blagonadezdine, V.I. (1986) La métallogénie de l'ordans le Précambrien de l'Afrique Occidentale. Université de Voronej. Université de Voronej, Russie, 171p.

[9] Bodin, L. (1951) Contribution à l'étude des granites birimiens de l'A.G.F. Bulletin Dir.Min. A. O.F., Dakar N6. Unpublished Report, 24-62.

[10] Grouchine, V.A., Jouravlev, V.M. Koupalov-Yaropolk, O.I., Kourtenkov, K.E. and Romanenko, V.N. (1972) Carte géologique schématique de la region du gisement de Kalana. Unpublished Report.

[11] Sangaré, S. (1994) Les facteurs pétrogénitiques de l'aurification dans la zone de Kalana (sud du Mali). Thèse Doct. Etat, Acad. Rech. Propect. Géol., Moscou, 238.

[12] Tourlytchkine, V., Malmatine, A., Légotkine, B., Matévossian, A., Béréjnoï, A. and Mamédov, A. (1982) Rapport définitif des travaux de prospection géologique du gisement de Kalana pour la période 1967 à 1982. Vol. 1 Kalana, Unpublished Report. 
[13] Masurel, Q., Mille, J., Ulrich, S., Hein, K.A.A., Hanssen, E., Kaisin, J. and Tessougue, S. (2015) The Yatela Gold Deposit in Mali, West Africa the Final Product of Long-Lived History of Hydrothermal Alteration and Weathering. Journal of African Earth Sciences, 113, 73-87.

[14] Kusnir, I. (1999) Gold in Mali. 311.

[15] Ballo, I., Hein, K.A.A., Guindo, B., Sanogo, L., Ouologuem, Y., Daou, G. and Traore, A. (2015) The Syama and Tabakoroni Goldfields, Mali. Ore Geology Reviews, 78, 578-585.

[16] Lambert-Smith, J.S., Lawrence, D.M., Vargas, C.A., Boyce, A.J., Treloar, P.J. and Herbert, S. (2015) The Gounkoto Au Deposit, West Africa: Constraints on Ore Genesis and Volatile Sources from Petrological, Fluid Inclusion and Stable Isotope Data. Ore Geology Reviews, 78, 606-622.

[17] Tshibubudze, A. and Hein, K.A.A. (2012) Structural Setting of Gold Deposits in the Oudalan-Gorouolvolcanosedimentary Belt East of the Markoye Shear Zone, West African Craton. Journal of African Earth Sciences, 80, 31-47.

[18] Hein, K.A.A., Matsheka, I.R., Bruguier, O., Masurel, Q., Bosch, D., Caby, R. and Monie, P. (2015) The Yatela Gold Deposit: 2 Billion Years in the Making. Journal of African Earth Sciences, 112, 548-569.

[19] Traoré, Y.D., Siebenaller, L., Salvi, S., Béziat, D. and Bouaré, M.L. (2015) Progressive Gold Mineralization along the Syama Corridor, Southern Mali (West Africa). Ore Geology Reviews, 78, 586-598.

Submit or recommend next manuscript to SCIRP and we will provide best service for you:

Accepting pre-submission inquiries through Email, Facebook, LinkedIn, Twitter, etc. A wide selection of journals (inclusive of 9 subjects, more than 200 journals)

Providing 24-hour high-quality service

User-friendly online submission system

Fair and swift peer-review system

Efficient typesetting and proofreading procedure

Display of the result of downloads and visits, as well as the number of cited articles

Maximum dissemination of your research work

Submit your manuscript at: http://papersubmission.scirp.org/

Or contact ojg@scirp.org 